\title{
Muscarinic receptor subtypes in rat pancreatic islets: binding and functional studies
}

\author{
Eugen J. Verspohl, Reinhold Tacke ${ }^{1}$, Ernst Mutschler ${ }^{2}$ and Günter Lambrecht ${ }^{2}$ \\ Department of Pharmacology, Institute of Pharmaceutical Sciences, University of Tübingen, Auf der Morgenstelle B, D-7400 Tübingen, \\ F.R.G., ' Institute of Inorganic Chemistry, University of Karlsruhe, D.7500 Karlsruhe, F.R.G., and ${ }^{2}$ Department of Pharmacology, \\ University of Frankfurt, D-6000 Frankfurt/M, F.R.G.
}

Received 17 November 1989, revised MS received 18 December 1989, accepted 9 January 1990

\begin{abstract}
Cholinergic agents are potent modulators of insulin release that act via muscarinic receptors. We now investigated the muscarinic receptor subtype present in rat pancreatic islets in binding and functional studies. Binding of $5 \mathrm{nM}$ $\left[{ }^{3} \mathrm{H}\right] \mathrm{N}$-methylscopolamine $\left(\left[{ }^{3} \mathrm{H}\right] \mathrm{NMS}\right)$ was half maximal at $30 \mathrm{~min}$. At $60 \mathrm{~min}$, the maximal total binding was $1.29 \%$ and the non-specific binding (presence of $100 \mu \mathrm{M}$ atropine) was $0.18 \%$ of the total radioactivity per $10 \mu \mathrm{g}$ islet protein. Unlabelled atropine inhibited $\left[{ }^{3} \mathrm{H}\right] \mathrm{NMS}$ binding with an $\mathrm{IC}_{50}$ of ca. $30 \mathrm{nM}$. The rank order of antagonist high-affinity binding was atropine $>$ sila-hexocyclium methyl sulfate $\left(\mathrm{SiHC} ; \mathbf{M}_{1}>\mathbf{M}_{3}>\mathrm{M}_{2}\right)>$ pirenzepine $\left(\mathrm{M}_{1}>\mathbf{M}_{2} \approx \mathbf{M}_{3}\right)=$ methoctramine $\left(M_{2}>M_{1}>M_{3}\right)$. The high-affinity $K_{d}$ s were $8.5,56,1300$ and $1300 \mathrm{nM}$, respectively. The high affinity $K_{d}$ of the muscarinic receptor agonist, arecaidine propargyl ester (APE), was $8.1 \mathrm{nM}$. The $\mathrm{EC}_{50}$ for the biological effects of APE on insulin and glucagon secretion was 3.2 and $2.3 \mathrm{nM}$. The rank order for the high-affinity biological effects of antagonists (inhibition of APE-mediated insulin/glucagon release) was almost the same as for binding. The data indicate that rat pancreatic islets contain neither an $\mathbf{M}_{1}$ subtype (high-affinity for pirenzepine) nor an $M_{2}$ subtype (high-affinity for methoctramine) receptor. However, the data evidence an $M_{3}$ receptor subtype, since SiHC in the absence of the $M_{1}$ receptor subtype shows a relatively high affinity to the receptors in rat pancreatic islets.
\end{abstract}

Muscarinic receptor subtypes; Islets of Langerhans (rat); Insulin; Glucagon

\section{Introduction}

The pancreatic islets of Langerhans are innervated by parasympathetic nervous fibres (Coupland, 1958) which are organized in a periinsular plexus with direct innervation to the cells (Miller, 1981). Cholinergic stimulation of insulin release is thought to participate in the secretory response of the pancreatic B-cell to food intake,

\footnotetext{
Correspondence to: E.J. Verspohl, Department of Pharmacology, Institute of Pharmaceutical Sciences, Auf der Morgenstelle B, D-7400 Tübingen, F.R.G.
}

e.g. in the cephalic phase of insulin secretion (Malaisse, 1972). The importance of cholinergic innervation for islet function is suggested by the 10-fold higher concentration of choline acetyltransferase in the islets versus that in the adjacent exocrine tissue (Godfrey and Matschinsky, 1975). In vivo and in vitro administration of muscarinic agonists stimulates insulin secretion (Malaisse, 1972). The stimulatory action of acetylcholine on the endocrine pancreas is abolished by atropine (Grill and Östenson, 1983; Kaneto and Kosaka, 1974; Holst et al., 1981; Honey and Weir, 1980); the $\mathrm{IC}_{50}$ for inhibition of acetylcholine-induced insulin release by the antagonist methylscopolamine is less than $0.4 \mathrm{nM}$ (Grill and Östenson, 
1983). Binding studies with $\left[{ }^{3} \mathrm{H}\right] \mathrm{N}$-methylscopolamine ([ $\left.{ }^{3} \mathrm{H}\right] \mathrm{NMS}$ ) (Malaisse et al., 1985) or

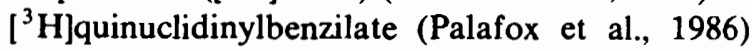
demonstrated the presence of muscarinic receptors in islets. The $\mathrm{IC}_{50}$ of inhibition of $\left[{ }^{3} \mathrm{H}\right] \mathrm{NMS}$ binding in rat pancreatic islets was approximately 5 $\mathrm{nM}$ when unlabelled $\mathrm{N}$-methylscopolamine was used (Östenson and Grill, 1985).

At least three different muscarinic receptor subtypes have been proposed on the basis of different affinities for antagonists such as pirenzepine (Hammer and Giachetti, 1982), methoctramine (Melchiorre, 1988; Melchiorre et al., 1987), AF-DX 116 (Micheletti et al., 1987) and hexahydro-sila-difenidol as well as sila-hexocyclium (SiHC; Lambrecht et al., 1988; Eltze et al., 1988; Waelbroeck et al., in press). The subtypes have been termed $M_{1}$ (neuronal type), $M_{2}\left(M_{2 \alpha}\right.$; cardiac type) and $M_{3}\left(M_{2 \beta}\right.$ smooth muscle/glandular type) receptors (for recent reviews see Mitchelson, 1988; Melchiorre, 1988; Mutschler et al., 1988). Five receptor subtypes were identified by molecular cloning studies and were found to be the products of distinct genes. These subtypes were termed $\mathrm{m} 1$ to $\mathrm{m} 5$ (Bonner et al., 1987; Buckley et al., in press). The antagonist binding properties of the individual cloned $\mathrm{m} 1, \mathrm{~m} 2$ and $\mathrm{m} 3$ receptors and their patterns of expression in various tissues correspond closely to those of the pharmacologically defined $M_{1}, M_{2}$ and $M_{3}$ receptors (Peralta et al., 1987; Akiba et al., 1988; Maeda et al., 1988; Buckley et al., in press).

The limited selectivity of available ligands has long hampered receptor subtype characterization in pancreatic islets. The results of functional studies ruled out the presence of $\mathbf{M}_{2}$ cardiac type receptors in mouse islets (Henquin and Nenquin, 1988) as well as that of the $M_{1}$ subtype in rat endocrine pancreas (Otsuki et al., 1985). In the present study an attempt was made to characterize the muscarinic receptor subtype in both functional and binding studies with rat islets of Langerhans. Pirenzepine $\left(M_{1}>M_{2} \approx M_{3}\right)$ (Hammer et al., 1980), methoctramine $\left(M_{2}>M_{1}>M_{3}\right)$ (Melchiorre et al., 1987; Melchiorre, 1988), and SiHC $\left(M_{1}>M_{3}>M_{2}\right)$ (Lambrecht et al., 1987; Waelbroeck et al., 1989) were used for the purpose.

\section{Materials and methods}

\subsection{Animals}

Wistar rats of either sex, weighing between 180 and $250 \mathrm{~g}$, were used. They were kept on a standard pellet diet (Altromin, Lage/Lippe, W. Germany) and tap water ad libitum at $22^{\circ} \mathrm{C}$ with a 12-h light/dark rhythm.

\subsection{Drugs and chemicals}

The following compounds were purchased or synthesized: atropine nitrate from Merck (Darmstadt, W. Germany), arecaidine propargyl ester (APE) (Mutschler and Hultzsch, 1973) and silahexocyclium ( $\mathrm{SiHC}$ ) (Tacke et al., 1989) synthesized in one of our laboratories. Pirenzepine dihydrochloride was from Boehringer Ingelheim (Ingelheim, FRG) and methoctramine (N, $N^{\prime}$-bis[6(2-methoxybenzyl)aminohexyl]-1,8-octanediamine) tetrahydrochloride was kindly provided by Dr. Carlo Melchiorre, University of Bologna (Italy). $\left[{ }^{3} \mathrm{H}\right] \mathrm{N}$-methylscopolamine $\left[{ }^{3} \mathrm{H}\right] \mathrm{NMS} ; 72 \mathrm{Ci} /$ $\mathrm{mmol}=2664 \mathrm{GBq} / \mathrm{mmol}$ ) was from Amersham Buchler (Braunschweig, W. Germany); pilocarpine hydrochloride, soybean trypsin inhibitor (SBTI), bacitracin and HEPES from Sigma Chemical Co. (St. Louis, MO); bovine serum albumin (BSA) fraction V from Miles Laboratories (Elkart, IN); collagenase (CLS grade) from Worthington Biochemicals Corp. (Freehold, NJ). Insulin radioimmunoassay kits were supplied by Isotopendienst West, GmbH (Dreieich, W. Germany). Rat insulin was purchased from the Novo Research Institute (Copenhagen, Denmark). The glucagon kit including glucagon standards was from Serono (Freiburg, W. Germany).

\subsection{Isolation of rat pancreatic islets}

The procedure for isolation of pancreatic islets was the one described by Lacy and Kostianovsky (1967) with slight modifications as described earlier (Verspohl and Ammon, 1980). Three rats were pretreated with $0.3 \mathrm{ml}$ of $4 \%$ pilocarpine hydrochloride i.p. The animals were killed with ether after $3 \mathbf{h}$ and the pancreases were isolated, minced, 
and washed twice with $20 \mathrm{ml}$ ice-cold Hanks solution containing $3.7 \mathrm{mM}$ glucose, $1 \mathrm{mg} / \mathrm{ml}$ bacitracin, $0.2 \mathrm{mg} / \mathrm{ml}$ SBTI and $0.2 \%$ albumin. Pancreas pieces were soaked and shaken in a water bath at $37^{\circ} \mathrm{C}$ in the presence of $650 \mathrm{U}$ collagenase $/ \mathrm{g}$ tissue suspension. After 15-18 min of incubation the tissue suspension was passed into $10 \mathrm{ml}$ of ice-cold Hanks solution. The islets were separated by sedimentation and collected as described elsewhere (Lacy and Kostianovsky, 1967). This method yields $300-500$ islets/rat pancreas. The islets were carefully selected in order to avoid contamination with exocrine tissue since the presence of muscarinic receptors on acini is well known.

\subsection{Binding experiments}

After the islets were isolated, they were washed in ice-cold Hanks solution using centrifugation. Fifty islets were incubated in $0.3 \mathrm{ml}$ Krebs-Ringer bicarbonate buffer plus $20 \mathrm{mM}$ HEPES (KRBH) buffer, $\mathrm{pH} 7.4$, containing $5 \mathrm{mg} / \mathrm{ml}$ bovine albumin, $1 \mathrm{mg} / \mathrm{ml}$ bacitracin and $0.1 \mathrm{mg} / \mathrm{ml} \mathrm{SBTI}$; $5 \mathrm{nM}\left[{ }^{3} \mathrm{H}\right] \mathrm{NMS}$, with or without $100 \mu \mathrm{M}$ unlabelled atropine, was then added. Binding experiments were performed in the presence of $16.7 \mathrm{mM}$ glucose since elevated binding has been shown clearly with long-term high glucose concentrations or hyperglycemia (Östenson and Grill, 1985; 1987). The incubation was terminated by cooling the samples $\left(4^{\circ} \mathrm{C}\right)$, and the incubation mixtures were then filtered through glass microfibre filters (Whatman GF/C, U.K.) for $2 s$ under reduced pressure. The filters were then washed twice with $0.2 \mathrm{ml}$ ice-cold KRBH-buffer, which took less than $15 \mathrm{~s}$. The dissociation experiment at $4^{\circ} \mathrm{C}$ illustrated in fig. 1 (dotted line) showed that no major dissociation was to be expected during the washing procedure. The filters were suspended in the scintillation cocktail (toluene, ethylene glycol monomethylether and 2,5-diphenyloxazole), shaken vigorously and counted in a $\beta$-scintillation spectrometer after luminescence had disappeared.

To establish the apparent receptor affinity (dissociation constant, $\mathbf{K}_{d}$ ) the competitive inhibition of specific $\left[{ }^{3} \mathrm{H}\right] \mathrm{NMS}$ binding by various concentrations of unlabelled antagonists was analyzed.
This was done by fitting plots for bound drugs versus free drugs by means of a non-linear leastsquares computer program that analyzed the data in terms of one non-saturable and one or two saturable components (Dixon, 1974).

\subsection{Insulin and glucagon secretion}

To measure insulin secretion, five islets were incubated for $60 \mathrm{~min}$ at $37^{\circ} \mathrm{C}$ in the aforementioned KRBH buffer after having been primed for $60 \mathrm{~min}$ with $16.7 \mathrm{mM}$ glucose. Insulin and glucagon released into the medium by the islets was assayed with radioimmunoassay kits using rat insulin or glucagon as a standard. Each compound had been checked for non-interference with the insulin and glucagon radioimmunoassays. For statistical evaluation of whole curves, multiple comparisons of means were carried out by two-way analysis of variance (F-test). Dunnett's test was used thereafter if several conditions were to be compared to the control experiments. $\mathrm{EC}_{50} \mathrm{~s}$ of biologic effects were determined by means of the RS/1 statistics pack (BBN Software Products Corp.).

\subsection{Protein determination}

The protein content was measured in extra batches within each binding experiment. The protein content of the solubilized pancreatic islets (solubilized with $0.1 \mathrm{~N} \mathrm{NaOH}$ ) was measured using bovine serum albumin as a standard (Bradford, 1976).

\section{Results}

\subsection{Time course of $\left[{ }^{3} \mathrm{H}\right] N M S$ binding}

The binding of $5 \mathrm{nM}\left[{ }^{3} \mathrm{H}\right] \mathrm{NMS}$ to isolated rat islets at $37^{\circ} \mathrm{C}$ was half maximal after $30 \mathrm{~min}$ and maximal binding occurred at $60 \mathrm{~min}$ (fig. 1). The velocity of binding was much lower than that shown earlier by Grill and Östenson (1983) and by Malaisse et al. (1985). At 60 min, maximal binding was $1.29 \%$ of added radioactivity per $10 \mu \mathrm{g}$ islet protein. Non-specific binding (determined in the 


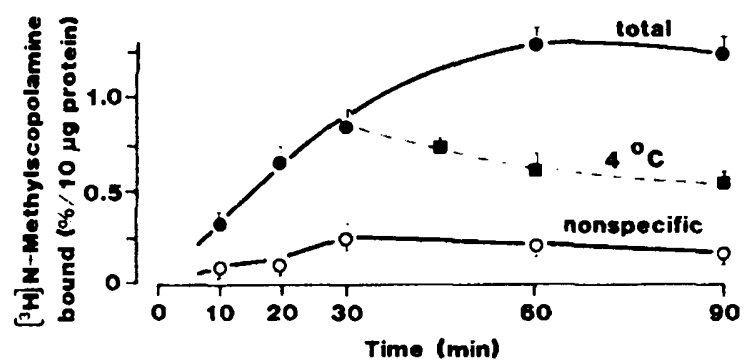

Fig. 1. Time course of $\left[{ }^{3} \mathrm{H}\right] \mathrm{NMS}$ binding to isolated rat islets of Langerhans. Fifty islets were incubated in $0.3 \mathrm{ml} \mathrm{KRH-al-}$ bumin buffer for $90 \mathrm{~min}$ at $37^{\circ} \mathrm{C}$ with $5 \mathrm{nM}\left[{ }^{3} \mathrm{H}\right] \mathrm{NMS}$ in the absence (0) and presence (0) of $0.1 \mathrm{mM}$ atropine. After washing at $30 \mathrm{~min}$ some batch-incubated islets were ro-incubated in radioactivity-free medium at $4^{\circ} \mathrm{C}$ in order to determine the dissociation velocity in the absence of ligands (a). The results are expressed as $\%$ bound per $10 \mu_{\mathrm{g}}$ islet protein. Each value represents the mean \pm S.E. of three to four separate experiments.

presence of $100 \mu \mathrm{M}$ atropine) ranged frum 0.10 to $0.26 \%$ of added radioactivity per $10 \mu \mathrm{g}$ islet protein. All subsequent binding studies were therefore carried out for $60 \mathrm{~min}$. At $30 \mathrm{~min}$, dissociation of

\section{TABLE 1}

Effects of muscarinic receptor agonists and various antagonists on receptor binding, insulin release and glucagon release. Activities were calculated as dissociation constants of high- and low-affinity binding $\left(K_{d 1}\right.$ and $K_{d 2}$ ) and as half maximally regulated insulin or glucagon release $\left(\mathrm{EC}_{50}\right)$ of high-affinity effect. The values were calculated from data shown in figs. 2-7. a NS vs. pirenzepine ( $P<0.05){ }^{b}$ NS vs. atropine $(P>0.05)$. Number of experiments in parentheses.

\begin{tabular}{lllll}
\hline Compound & $\begin{array}{l}\mathrm{K}_{\mathrm{d} 1} \\
(\mathrm{nM})\end{array}$ & $\begin{array}{l}\mathrm{K}_{\mathrm{d} 2} \\
(\mathrm{nM})\end{array}$ & \multicolumn{2}{l}{$\mathrm{EC}_{\mathrm{s0}}(\mathrm{nM})$} \\
\cline { 4 - 5 } & & & $\begin{array}{l}\text { Insulin } \\
\text { secretion }\end{array}$ & $\begin{array}{l}\text { Glucagon } \\
\text { secretion }\end{array}$ \\
\hline Agonist & & & & \\
APE & $8.06(4)$ & $5840(4)$ & $3.23(12)$ & $2.34(12)$ \\
& \pm 1.04 & \pm 631 & \pm 0.25 & \pm 0.31 \\
Antagonists & & & & \\
Atropine & $8.46(4)$ & $463(4)$ & $9.18(3)$ & $11.3(3)$ \\
& \pm 1.13 & \pm 54 & \pm 0.94 & \pm 0.99 \\
SiHC & $55.6(4)$ & $1940(4)$ & $6.32(3)$ & $364(3)$ \\
& \pm 3.89 & \pm 128 & \pm 1.03 & \pm 27.3 \\
Pirenzepine & $1340(4)$ & $9100(4)$ & $432(4)$ & $1510(4)$ \\
& \pm 211 & \pm 641 & \pm 22.6 & \pm 213 \\
Methoctramine & $1280(4)$ & $55000(4)$ & $2130(3)$ & $2380(3)$ \\
& \pm 154 & \pm 6100 & \pm 198 & \pm 468 \\
\hline
\end{tabular}

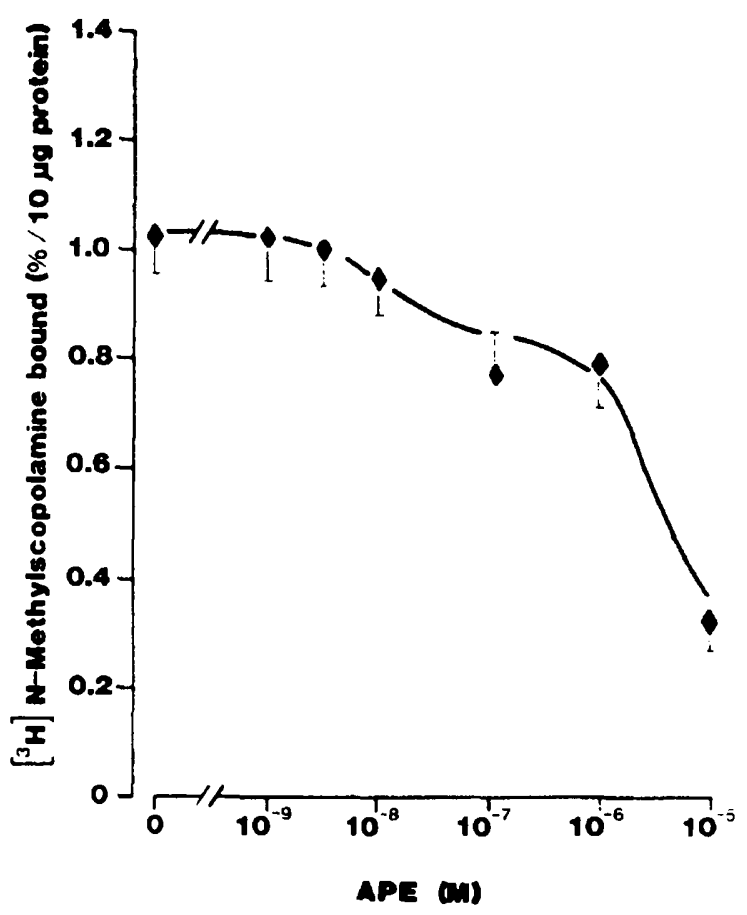

Fig. 2. Inhibition by the agonist, $A P E$, of [ $\left.{ }^{3} \mathbf{H}\right] \mathbf{N M S}$ binding to isolated rat islets of Langerhans. Fifty islets were incubated in $0.3 \mathrm{ml} \mathrm{KRH}$-albumin buffer for $60 \mathrm{~min}$ at $37^{\circ} \mathrm{C}$ with $5 \mathrm{nM}$ $\left[{ }^{3} \mathrm{H}\right] \mathrm{NMS}$ and increasing concentrations of agonist. The results are expressed as $\%$ bound per $10 \mu \mathrm{g}$ islet protein. Each value represents the mean $\pm S$.E. of four separate experiments.

labeled ligand at $4^{\circ} \mathrm{C}$ was slow, i.e. the half life was more than $60 \mathrm{~min}$.

\subsection{Muscarinic receptor agonist, APE}

APE inhibited $\left[{ }^{3} \mathrm{H}\right] \mathrm{NMS}$ binding in a concentration-related manner (fig. 2). Inhibition was essentially complete over four orders of magnitude (1-10000 $\mathrm{nM})$. Binding analysis of the competition-inhibition curve revealed more than a single binding site with a $K_{d 1}$ of $8.06 \mathrm{nM}$ and $K_{d 2}$ of $5840 \mathrm{nM}$ (table 1 ) and a capacity of $\mathrm{B}_{\max 1}=36.8$ and $B_{\max 2}=91.9 \mathrm{fmol} / 10 \mu \mathrm{g}$ islet protein.

In rat pancreatic islets, glucose alone (absence of muscarinic receptor agonist) increased insulin release (fig. 3). APE increased insulin release in a dose-dependent biphasic manner that was independent of the glucose concentration $(3.0 \mathrm{mM}=$ substimulatory and $16.7 \mathrm{mM}=$ stimulatory). Glu- 


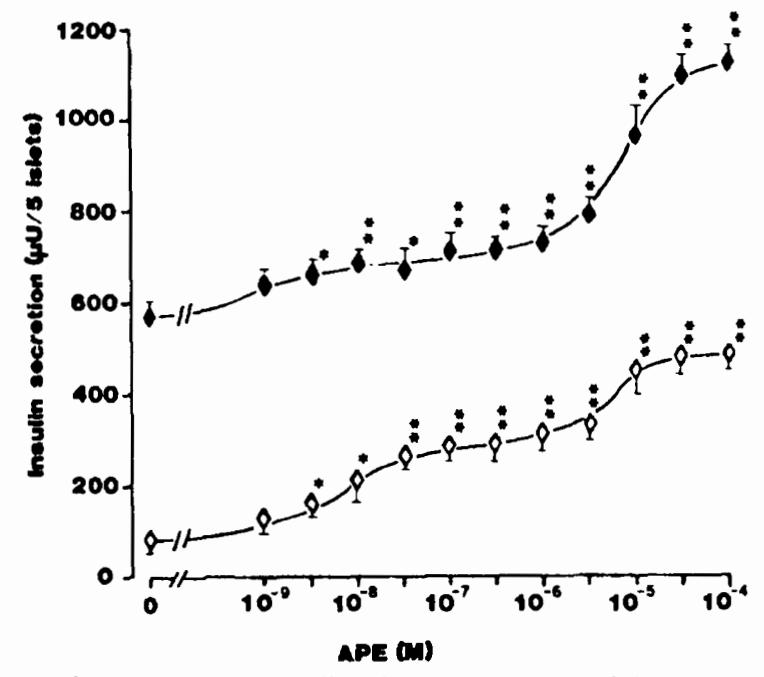

Fig. 3. Stimulation of insulin release by the muscarinic receptor agonist, APE. Five islets were incubated in the same buffer with various APE concentrations for $60 \mathrm{~min}$ at $37^{\circ} \mathrm{C}$ in the presence of non-stimulatory glucose $(3.0 \mathrm{mM}(\diamond))$ or stimulatory glucose $(16.7 \mathrm{mM}(\diamond))$. The results are expressed as $\mu \mathrm{U}$ insulin secreted per five islets over $60 \mathrm{~min}$. Each value represents the mean \pm S.E. of 12 separate experiments $(F=5.12$, $P<0.01$ at $16.7 \mathrm{mM}$ glucose; $F=4.46, P<0.01$ at $3 \mathrm{mM}$ glucose; ${ }^{*} \mathrm{P}<0.05$ and ${ }^{*}{ }^{*} \mathrm{P}<0.01$ both vs. absence of $\mathrm{APE}$ ).

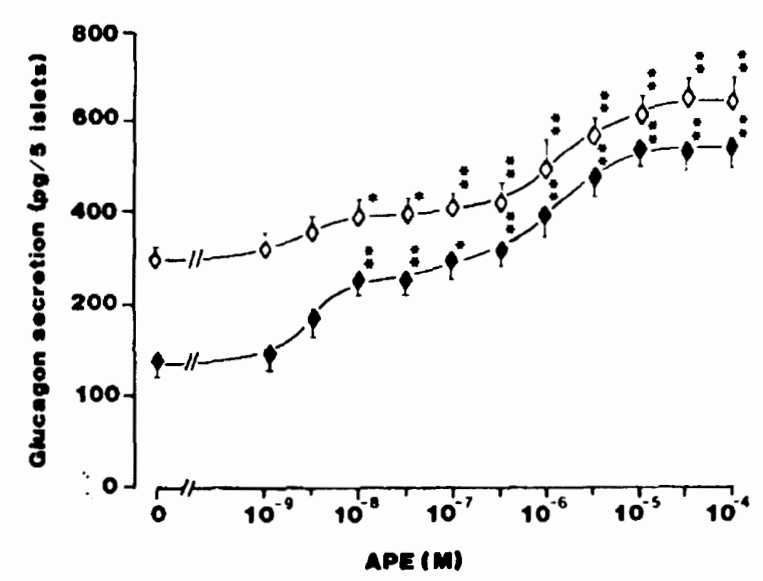

Fig. 4. Stimulation of glucagon release by the muscarinic receptor agonist, APE. Five islets were incubated in the same buffer with various APE concentrations for $60 \mathrm{~min}$ at $37^{\circ} \mathrm{C}$ in the presence of non-stimulatory glucose $(3.0 \mathrm{mM}, \diamond)$ or stimulatory glucose $(16.7 \mathrm{mM}, \diamond)$. The results are expressed as pg glucagon secreted per five islets over $60 \mathrm{~min}$. Each value represents the mean \pm S.E. of 12 separate experiments $(F=4.93$, $P<0.02$ at $3 \mathrm{mM}$ glucose; $F=4.31, P<0.01$ at $16.7 \mathrm{mM}$ glucose; ${ }^{*} \mathrm{P}<0.05$ and ${ }^{* *} \mathrm{P}<0.02$ both vs. absence of $\mathrm{APE}$ ).

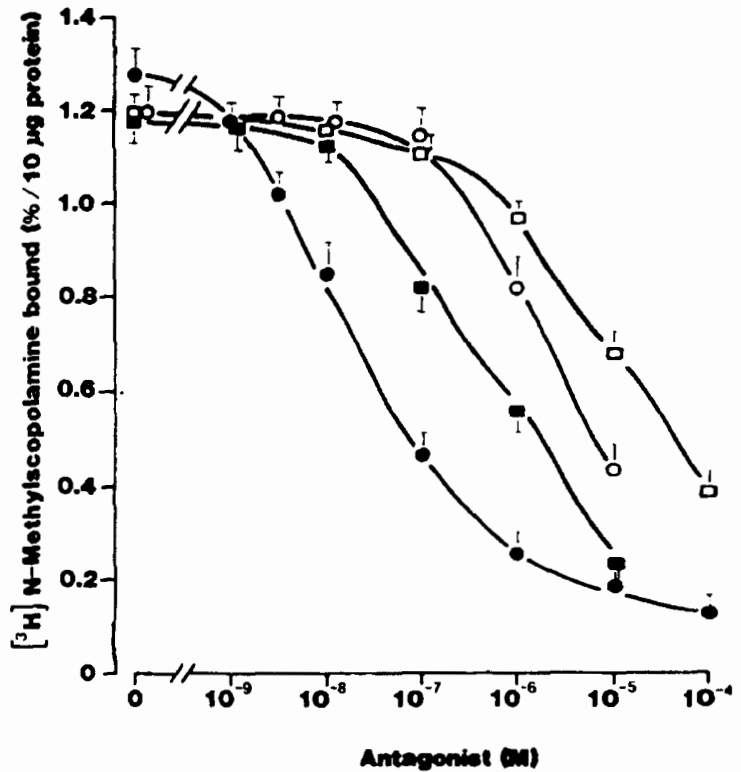

Fig. 5. Inhibition of $\left[{ }^{3} \mathrm{H}\right] \mathrm{NMS}$ binding to isolated rat islets of Langerhans by antagonists: 50 islets were incubated in $0.3 \mathrm{ml}$ KRH-albumin buffer for $90 \mathrm{~min}$ at $37^{\circ} \mathrm{C}$ with $5 \mathrm{nM}\left[{ }^{3} \mathrm{H}\right] \mathrm{NMS}$ and increasing concentrations of antagonists. The antagonists were: $(\bullet)$ atropine, $(\varpi)$ SiHC, (O) pirenzepine, $(\square)$ methoctramine. The results are expressed as $\%$ bound per $10 \mu \mathrm{g}$ islet protein. Each value represents the mean \pm S.E. of four separate experiments.

cose alone (absence of muscarinic receptor agonist) decreased glucagon release (fig. 4). APE increased glucagon release in a dose-dependent biphasic manner at both 3.0 and $16.7 \mathrm{mM}$ glucose.

\subsection{Muscarinic receptor antagonists}

The concentration of unlabelled atropine causing half maximal inhibition of $\left[{ }^{3} \mathrm{H}\right] \mathrm{NMS}$ binding was ca. $30 \mathrm{nM}\left(\mathrm{IC}_{50}\right)$ (fig. 5). Binding analysis of the competition-inhibition curves generated with unlabelled antagonists revealed more than a single binding site with Hill coefficients of less than 0.6 in all cases. For atropine, e.g. $\mathrm{K}_{\mathrm{d} 1}$ was $8.46 \pm 1.13$ and $K_{d 2}$ was $463 \pm 54 \mathrm{nM}$, respectively. The rank order for inhibition of antagonist high-affinity binding was atropine $>\mathrm{SiHC}>$ pirenzepine $=$ methoctramine (table 1).

When islets were stimulated by $10 \mu \mathrm{M}$ APE in the presence of $16.7 \mathrm{mM}$ glucose, muscarinic re- 
ceptor antagonists inhibited insulin release (fig. 6). The rank order of potency was atropine $=\mathrm{SiHC}>$ pirenzepine $>$ methoctramine (table 1). No antagonist lowered insulin release below the values obtained with glucose alone (fig. 6), and no antagonist antagonized the effect of glucose alone (data not shown).

In the presence of $3 \mathrm{mM}$ glucose plus $10 \mu \mathrm{M}$ APE, muscarinic receptor antagonists inhibited glucagon release (fig. 7). The rank order of potency was atropine $>\mathrm{SiHC}>$ pirenzepine $=$ methoctramine (table 1). Atropine, but not other antagonists lowered glucagon release below values obtained with glucose alone (fig. 7).

\section{Discussion}

\subsection{Muscarinic receptor agonist}

Our data clearly show that muscarinic binding sites are present on rat pancreatic islets. APE

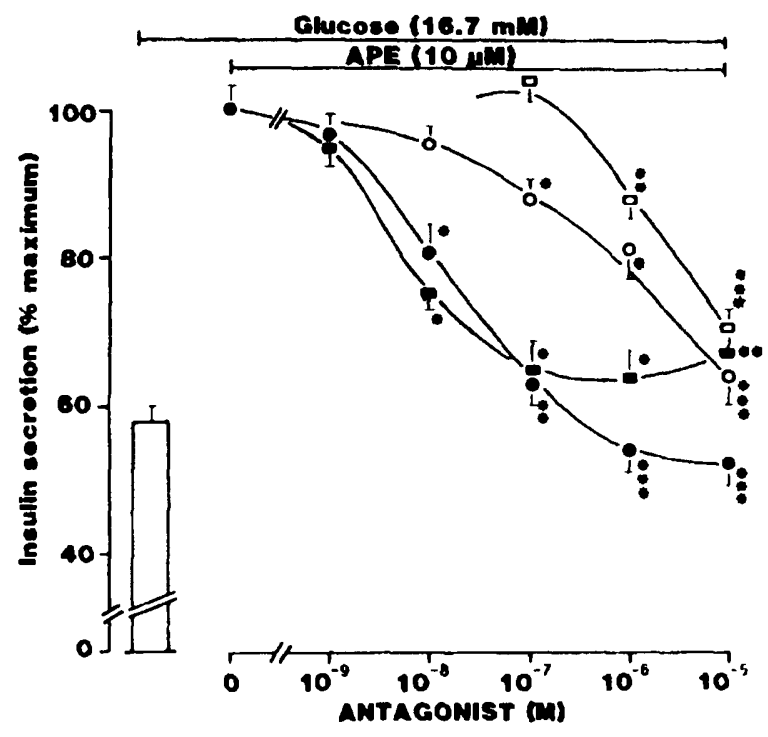

Fig. 6. Inhibition of APE-stimulated insulin release by muscarinic receptor antagonists. Five islets were incubated with increasing concentrations of antagonists in the presence of $16.7 \mathrm{mM}$ glucose plus $10 \mu \mathrm{M} \mathrm{APE}$ for $60 \mathrm{~min}$ at $37^{\circ} \mathrm{C}$. The

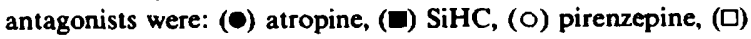
methoctramine. The results are expressed as maximal $\%$ secreted insulin. Each value represents the mean \pm S.E. of three separate experiments $(* P<0.05, * * P<0.02, * * * P<0.001$ vs. absence of antagonists).

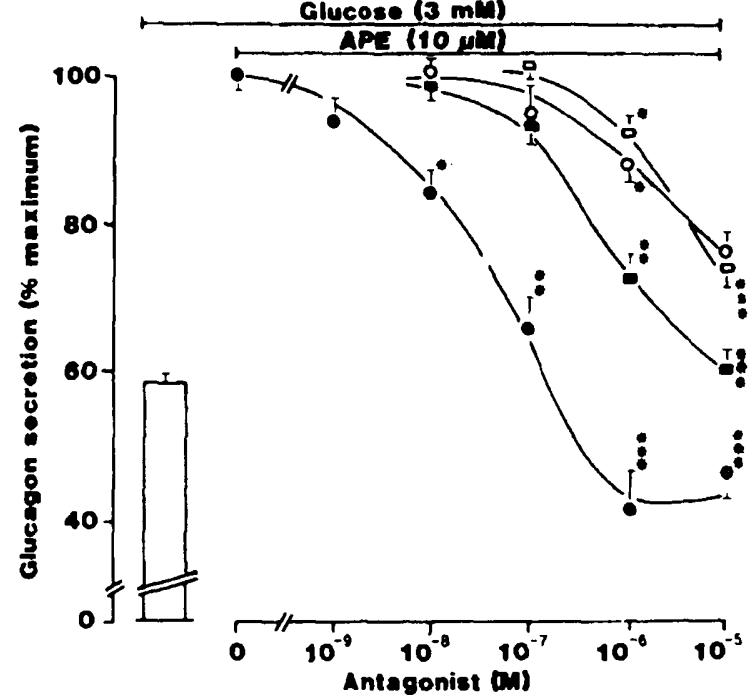

Fig. 7. Inhibition of APE-stimulated glucagon release by muscarinic receptor antagonists. Five islets were incubated with increasing concentrations of antagonists in the presence of $3.0 \mathrm{mM}$ glucose plus $10 \mu \mathrm{M} \mathrm{APE}$ for $60 \mathrm{~min}$ at $37^{\circ} \mathrm{C}$. The

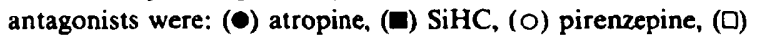
methoctramine. The results are expressed as maximal $\%$ secreted glucagon. Each value represents the mean \pm S.E. of three separate experiments $(* P<0.05, * * P<0.01, * * * P<0.001$ vs. absence of antagonists).

which is selective for muscarinic over nicotinic receptors inhibits $\left[{ }^{3} \mathrm{H}\right] \mathrm{NMS}$ binding and stimulates both insulin and glucagon release at similar concentrations in a biphasic, dose-dependent manner.

\subsection{Muscarinic receptor antagonists}

Since no agonists selective for muscarinic receptor subtypes are available, antagonist were now used to characterize the muscarinic receptor subtype in rat pancreatic islets. There was a clear rank order of affinity: the highest affinity was found for the compound, SiHC, which exhibits a similar affinity for $\mathbf{M}_{1}$ and for $\mathbf{M}_{3}$ receptors (Lambrecht et al., 1987; Waelbroeck et al., in press). The low affinity of pirenzepine indicates that the $M_{1}$ subtype is not important and the low affinity of methoctramine indicates that $\mathbf{M}_{2}$ receptor subtypes are not predominant in rat pancreatic islets. The $\mathbf{M}_{3}$ receptor subtype also appears to be 
that most involved in A-cells. This receptor subtype had originally been named $\mathbf{M}_{\mathbf{4}}$. Functional data reported by Henquin and Nenquin (1988) make it likely that this subtype is involved in islets effects.

\subsection{Initiating or modulating effect of a muscarinic receptor agonist?}

Ambient glucose stimulates insulin secretion and inhibits glucagon secretion (Verspohl and Ammon, 1987). The muscarinic receptor agonist, APE, both initiates and modulates insulin release. The fact that, in contrast to Hermans et al. (1986), we were able to show an initiating (absence of stimulatory glucose) insulinotropic effect of a muscarinic receptor agonist may have been due to species differences (mouse) or to the fact that our islets were primed by an 1-h preincubation in the presence of $16.7 \mathrm{mM}$ glucose or been the result of using a highly specific agonist in contrast to other groups.

The muscarinic receptor agonist, APE, is able to modulate the glucose-mediated inhibition of glucagon release. Our data confirm those of Östensen and Grill (1985) by showing that muscarinic receptor antagonists inhibit the glucagon release stimulated by cholinergic substances.

The receptor subtype population cannot be decided from binding studies alone since rat pancreatic islets are a heterogenous cell population which may obscure a receptor subtype on a cell type which is only present in low amounts. The functional data nevertheless indicate, first that the measured binding sites are related to the $B$ and $A$ cells of rat pancreatic islets and, second, that the muscarinic receptor agonist had an insulinotropic and glucagonotropic effect independent of the glucose concentration used.

\subsection{Extrapolation of the in vitro situation}

These in vitro data will need further evaluation from in vivo experiments since atropine and possibly other antagonists have been claimed based on the in vivo experiments, to behave differently by not being selective. Atropine and pirenzepine not only do antagonize muscarinic effects but they also antagonize secretin and cholecystokinin- mediated effects (Otsuki et al., 1987; You and Chey, 1988).

Taken together, our data are consistent with the opinion that rat pancreatic islets contain $\mathrm{M}_{3}$ muscarinic subtypes as also does the exocrine pancreas (Louie and Owyang, 1985; Dehaye et al., 1983). Identifying selective $M_{3}$ agonist interacting with the endocrine pancreas but hopefully not with other glands would provide a valuable tool for the development of new insulinotropic drugs. In conclusion, the binding and functional data indicate the predominant presence of an $M_{3}$ receptor subtype in the rat pancreatic islets.

\section{Acknowledgements}

The expert technical assistance of Mrs. I. Breuning is acknowledged. This work was supported by the Deutsche Forschungsgemeinschaft, Bonn-Bad Godesberg, FRG (Ve 90/3-1, Ta 75/5-1). R.T., E.M. and G.L. thank the Fonds der Chemischen Industrie for financial support.

\section{References}

Akiba, I., T. Kubo, A. Maeda, H. Bujo, J. Nakai, M. Mishina and S. Numa, 1988, Primary structure of porcine muscarinic acetylcholine receptor 111 and antagonist binding studies, FEBS Lett. 235, 257.

Bonner, T.I., N.J. Buckley, A. Young and M.R. Brann, 1987, Identification of a family of muscarinic receptor genes, Science 237, 527.

Bradford, M., 1976, A rapid and sensitive method for the quantitation of microgram quantities of protein utilizing the principle of protein dye binding. Anal. Biochem. 72 , 248.

Buckley, N.J., T.I. Bonner, C.M. Buckley and M.R. Brann, Antagonist binding properties of five cloned muscarinic receptors expressed in CHO-K1 Cells, Mol. Pharmacol. (in press).

Coupland, R.E., 1958, The innervation of pancreas of the rat, cat and rabbit as revealed by the cholinesterase technique, J. Anat. 92, 143.

Dehaye, J.-P., J. Winand, L. Hermans, P. Poloczek and J. Christophe, 1983, Inhibitory effects of pirenzepine on muscarinic stimulation of rat pancreas, European J. Pharmacol. 92, 259.

Dixon, W.J., 1974, BMD Biomedical Computer Programs (University of California, Berkeley, CA).

Eltze, M., G. Gmelin, J. Wess, C. Strohmann, R. Tacke, E. Mutschler and G. Lambrecht, 1988, Presynaptic muscarinic receptors mediating inhibition of neurogenic contractions 
in rabbit vas deferens are of the ganglionic $M_{1}$ type, European J. Pharmacol. 158, 233.

Godfrey, D.A. and F.M. Matschinsky, 1975, Enzymes of the cholinergic system in islets of Langerhans, J. Histochem. Cytochem. 23, 645.

Grill, V. and C.-G. Östenson, 1983, Muscarinic receptor in pancreatic islets of the rat. Demonstration and dependence on long-term glucose environment, Biochim. Biophys. Acta $756,159$.

Hammer, R., C.P. Berrie, N.J.M. Birdsall, A.S.V. Burgen and E.C. Hulme, 1980, Pirenzepine distinguishes between different subclasses of muscarinic receptors, Nature 283, 90.

Hammer, R. and A. Giachetti, 1982, Muscarinic receptor subtypes: $M_{1}$ and $M_{2}$, biochemical and functional characterization, Life Sci. 31, 2991.

Henquin, J.-C. and M. Nenquin, 1988, The muscarinic receptor subtype in mouse pancreatic B-cells, FEBS Lett. 236, 89.

Hermans, M.P., W. Schmeer and J.-C. Henquin, 1986, Why is acetylcholine a potentiator and not an initiator of insulin release?, Diabetologia 29, 511 (Abstract No. 212).

Holst, J.J., O.B. Schaffalitzky de Muckadell, J. Fahrenkrug, S. Lindkaer, O.V. Nielsen and T.W. Schwartz, 1981, Nervous control of pancreatic endocrine secretion in pigs. III. The effect of acetylcholine on the pancreatic secretion of insulin and glucagon, Acta Physiol. Scand. 115, 15.

Honey, R.N. and G.C. Weir, 1980, Acetylcholine stimulates insulin, glucagon, and somatostatin release in the perfused chicken pancreas, Endocrinology 107, 1065.

Kaneto, A. and K. Kosaka, 1974, Stimulation of glucagon and insulin secretion by acetylcholine infused intra-pancreatically, Endocrinology 95, 676.

Lacy, P.E. and M. Kostianovsky, 1967, Method for the isolation of intact islets of Langerhans from the rat pancreas, Diabetes 16, 35.

Lambrecht, G., R. Feifel, B. Forth, C. Strohmann, R. Tacke and E. Mutschler, 1988, p-Fluoro-hexahydro-sila-difenidol: The first $\mathbf{M}_{2 \beta}$-selective muscarinic antagonist, European $\mathrm{J}$. Pharmacol. 152, 193.

Lambrecht, G., E. Mutschler, U. Moser, J. Riotte, M. Wagner, J. Wess, G. Gmelin, R. Tacke and H. Zilch, 1987, Heterogeneity in muscarinic receptors: evidence from pharmacological and electrophysiological studies with selective antagonists, in: Int. Symp. on Muscarinic Cholinergic Mechanisms, eds. S. Cohen and M. Sokolovsky (Freund Publishing House, London) p. 245.

Louie, D. and C. Owyang, 1985, Characterization of muscarinic receptor subtypes mediating amylase secretion from pancreatic acini: secretion and binding studies, Gastroenterology 88, 1481 (Abstract).

Maeda, A., T. Kubo, M. Mishina and S. Numa, 1988, Tissue distribution of $m R$ NAs encoding muscarinic acetylcholine receptor subiypes, FEBS Lett. 239, 339.

Malaisse, W.J., 1972 in: Handbook of Physiology, Sect. 7, Vol. 1. Endocrine pancreas, eds. D.F. Steiner and N. Freinkel (American Phsyiological Society, Washington, DC, Williams and Wilkins, Baltimore) p. 237.

Malaisse, W.J., M. Mahy and P.C.F. Mathias, 1985, Binding of $\left.{ }^{3} \mathrm{H}\right] \mathrm{N}$-methylscopolamine to rat pancreatic islets, IRCS Med. Sci. 13, 503.

Melchiorre, C., 1988, Polymethylene tetramines: a new generation of selective muscarinic antagonists, Trends Pharmacol Sci. 9, 216.

Melchiorre, C.. P. Angeli, G. Lambrecht, E. Mutschler, M.T. Picchio and J. Wess, 1987, Antimuscarinic action of methoctramine, a new cardioselective $M_{2}$ muscarinic receptor antagonist, alone and in combination with atropine and gallamine, European J. Pharmacol. 144, 117

Micheletti, R., E. Montagna and A. Giachetti, 1987, AF-DX 116, a cardioselective muscarinic antagonist, J. Pharmacol Exp. Ther. 241, 628

Miller. R.E., 1981, Pancreatic neuroendocrinology: Peripheral neural mechanisms in the regulation of the islets of Langerhans, Endocrinol. Rev. 4, 471.

Mitchelson, F., 1988, Muscarinic receptor differentiation, Pharmacol. Ther. 37, 357.

Mutschler, E. and K. Hultzsch, 1973, Structure-activity relationships of unsaturated esters of arecaidine and dihydroarecaidine, Arzneim. Forsch. 23, 732.

Mutschler, E., U. Moser, J. Wess and G. Lambrecht, 1988, New approaches to the subclassification of muscarinic receptors, in: Recent Advances in Receptors Chemistry, eds C. Melchiorre and M. Gianella (Elsevier Science Publishers B.V., Amsterdam) p. 195

Östenson, C.-G. and V. Grill, 1985, Glucose exerts opposite effects on muscarinic receptor binding to $A$ and $B$ cells of the endocrine pancreas, Endocrinology 116, 1741.

Östenston, C.-G. and V. Grill, 1987, Evidence that hyperglycemia increases muscarinic binding in pancreatic islets of the rat, Endocrinology 121, 1705.

Otsuki, M., T. Nakamura, Y. Okabayashi, T. Oha, M. Fujii and S. Baba, 1985, Comparative inhibitory effects of pirenzepine and atropine on cholinergic stimulation of ex. ocrine and endocrine rat pancreas, Gastroenterology 89 , 408.

Otsuki, M., Y. Okabayashi, T. Nakamura, M. Fujia, T. Oka, S. Tani and S. Baba, 1987, Inhibitory effects of pirenzepine on cholecystokinin and secretin stimulation of exocrine and endocrine rat pancreas, Dig. Dis. Sci. 32, 1136.

Palafox, I., J.V. Sanchez-Andres, S. Sala, R. Ferrer and B. Soria, 1986, In: Biophysics of the Pancreatic B-Cell, eds. I. Atwater, E. Rojas and B. Soria (Planum Press, New York), p. 351.

Peralta, E.G., A. Ashkenazi, J.W. Winslow, D.H. Smith, J. Ramachandran and D.J. Capon, 1987, Distinct primary structures, ligand-binding properties and tissue-specific expression of four human muscarinic acetylcholine receptors. EMBO J. 6, 3923.

Tacke, R., H. Linoh, K. Rafeiner, G. Lambrecht and E Mutschler, 1989, Synthese und Eigenschaften des selektiven Antimuscarinikums Sila-Hexocyclium-Methylsulfat, J. Organomet. Chem. 359, 159.

Verspohl, E.J. and H.P.T. Ammon, 1980, Evidence for presence of insulin receptors in rat islets of Langerhans, J. Clin. Invest. $65,1230$. 
Verspohl, E.J. and H.P.T. Ammon, 1987, Cholecystokinin $\left(\mathrm{CCK}_{8}\right)$ regulates glucagon, insulin, and somatostatin secretion from isolated rat pancreatic islets: interaction with glucose, European J. Physiol. 410, 248.

Waelbroeck, M., M. Tastenoy, J. Camus, J. Christophe, C. Strohmann, H. Linoh, H. Zilch, R. Tacke, E. Mutschler and G. Lambrecht, Binding and functional properties of anti- muscarinics of the hexocyclium/sila-hexocyclium and hexahydro-difenidole hexahydro-sila-difenidol type to muscarinic receptor subtypes, Br. J. Pharmacol. (in press). You, C.H. and W.Y. Chey, 1988, Atropine abolishes the potentiation effect of secretin and cholecystokinin-octapeptide on exocrine pancreatic secretion in humans, Pancreas 3, 99. 